\title{
FEMALE PROSTITUTION, HYGIENE, AND MEDICINE IN ANCIENT GREECE: A PECULIAR RELATIONSHIP
}

\section{Gregory TSOUCALAS ${ }^{1}$, Spyros N. MICHALEAS ${ }^{2}$, Georges ANDROUTSOS ${ }^{3}$, Nikolaos VLAHOS ${ }^{4}$, Marianna KARAMANOU ${ }^{2,3} \bowtie$}

${ }^{1}$ History of Medicine, Anatomy Department, Medical School, Democritus University of Thrace, Alexandroupolis, Greece

${ }^{2}$ Department of History of Medicine and Medical Ethics, Medical School, National and Kapodistrian University of Athens, Athens, Greece

${ }^{3}$ Biomedical Research Foundation, Academy of Athens, Athens, Greece

${ }^{4} 2^{\text {nd }}$ Department of Obstetrics and Gynaecology, "Aretaieion" Hospital, National and Kapodistrian University of Athens, Athens, Greece

\section{Abstract}

In ancient Greece, many textbooks were written in order to provide comprehensive, pioneering, and ingenious guides on the philosophy and medical aspects of sexual behaviour. Unfortunately, only fragments of these texts have survived among the treatises from Greek and Roman antiquity. The aim of this study is to examine these texts and understand the triad of the female prostitution-hygiene-medicine in ancient Greek populations. We conduct a thorough study of ancient texts, using PubMed, Google Scholar, and medical libraries of Athens, Greece. Prostitution in ancient Greece symbolized both lust and sexual freedom of women, while at the same time it could signal the relationship of female potency to control men. Most prostitutes served men in need of medical and psychological services. They also addressed issues like physical violence, sexually transmitted infections, post-traumatic stress, and unplanned pregnancies. The contribution of female prostitution in ancient Greece, demonstrates the polysemous development of terms

\section{Résumé}

Prostitution féminine, hygiène et médecine dans la Grèce antique : une relation particulière

Dans la Grèce antique, de nombreux manuels ont été rédigés afin de fournir des guides complets, novateurs et ingénieux sur la philosophie et les aspects médicaux du comportement sexuel. Malheureusement, seuls des fragments de ces textes ont survécu parmi les traités de l'antiquité grecque et romaine. Le but de cette étude est d'examiner ces textes et de comprendre la triade prostitution-hygiène-médecine féminine dans les populations de la Grèce antique. Nous avons effectué une étude approfondie des textes anciens, en utilisant PubMed, Google Scholar et les bibliothèques médicales d'Athènes, en Grèce. La prostitution dans la Grèce antique symbolisait à la fois la luxure et la liberté sexuelle des femmes, tout en signalant en même temps la relation entre la puissance féminine et le contrôle des hommes. La plupart des prostituées servaient des hommes qui avaient besoin de services 
such as «sexual pleasure», «lust», and «eroticism» in the medico-philosophical texts of that era.

Keywords: sexual medicine, hetaira, medical literature, ancient Greece.

\section{INTRODUCTION}

In ancient Greece, many textbooks were written to provide comprehensive, pioneering, and ingenious guides on the philosophy and medical aspects of sexual behaviour. At that time, the studies of medicine and philosophy were strongly connected and taught simultaneously. These works did not surpass the ancient Indian Hindu masterpiece, the Kama Sutra, but they did demonstrate how ancient Hellenic culture viewed sexual pleasure as both practical and virtuous. Unfortunately, only fragments of these texts have survived among the treatises from Greek and Roman antiquity. Moreover, modern societal attitudes towards sex in the Western world have restricted analysis of these texts to those with a keen interest in history and art. The prostitute of that era symbolized erotic imagination and sexual freedom while also signalling the power exerted over men. This chapter thus examines these fragments to help understand the peculiar relationships that evolved between female prostitution, hygiene, and medicine in ancient Greek populations.

\section{Female prostitution in ancient Greece}

Ancient Greek society had views of morality and erotic expression that differed greatly from those of modern society. Ancient Greeks considered sex to be an intense, constant hormesis (Greek: ó $\rho \mu \eta \sigma \iota s$, or spurt or effusion of pleasures) towards hedonism

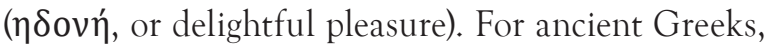
this terpsis ( $\tau \dot{\varepsilon} \rho \psi \iota \varsigma$, or joyful pleasure) was virtuous. They acknowledged and participated in a wide range of physical pleasure-seeking, including orgies, fetishes, self-stimulation, polygamy, symposia, homosexuality, paedophilia, pederasty, Dionysian orgies, marital sex, oneiroxis (oveí $\rho \omega \xi \eta$, or wet dreams), algehedone $\left(\alpha \lambda \gamma \eta \delta\right.$ ov ${ }^{\prime}$, or painful pleasure), and imaginary sex with gods. ${ }^{1}$ In addition to using sex for perpetuation of the species, the ancient Greeks believed that sex helped to balance psychic homeostasis, which was an médicaux et psychologiques. Elles ont également abordé des problèmes tels que la violence physique, les maladies sexuellement transmissibles, le stress post-traumatique et les grossesses non planifiées. La contribution de la prostitution féminine dans la Grèce antique démontre le développement polysémique des termes tels que "plaisir sexuel", «luxure» et «érotisme» dans les textes médico-philosophiques de cette époque.

Mots-clés: médecine sexuelle, hétaïre, littérature médicale, Grèce ancienne.

integral component of a healthy life. ${ }^{2-4}$ Pornography thus served as a source of medical information in Greek antiquity.

The Hellenic term porne ( $\pi$ ó $\rho \eta \eta$, or female prostitute) derives from the ancient Greek verb pernemi ( $\pi \varepsilon \dot{\varepsilon} \rho \eta \mu \mathrm{l}$, or to sell), as shown in Figure 1. These women could belong to several categories. First, the deiktiriades ( $\Delta \varepsilon \iota \kappa \tau \eta \rho\llcorner\alpha \dot{\delta} \delta \varepsilon \varsigma$, or someone who is pointed at, as in a common prostitute) worked in cheap

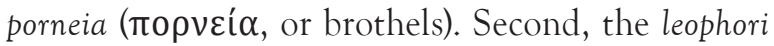

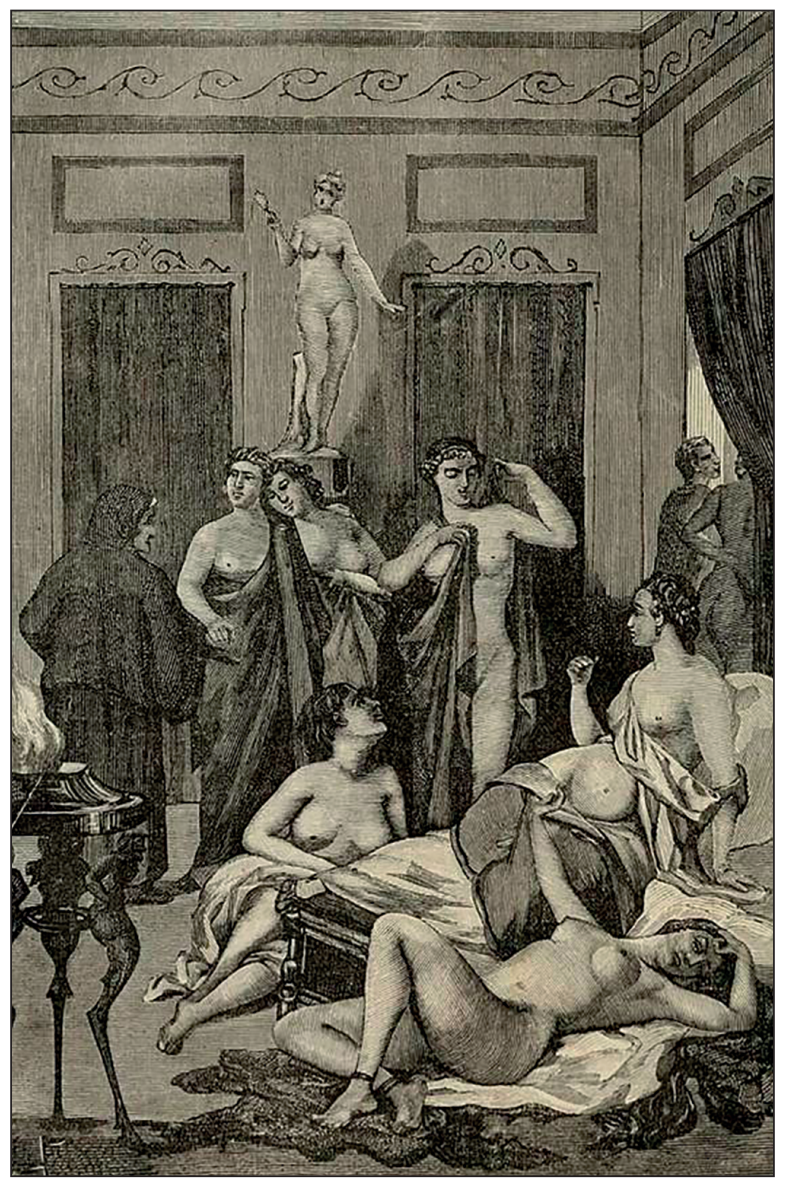

Figure 1. An ancient Greek Brothel, 19th century engraving from the treatise "History of Prostitution", P.L. Jacobs, 1885. 
( $\Lambda \varepsilon \omega \varphi$ ó $\rho$ ol, or cheap prostitutes) served clients in the public streets. Third, the chametypai (X $\alpha \mu \alpha i \tau u \pi \alpha \iota)$ were more expensive than leophori and they copulated in public areas or on the ground. Fourth, the hetaires

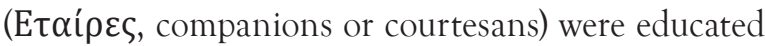
women who often befriended men, attended philosophical meetings, and even wrote medico-philosophical treatises and exercised medicine as physicians. ${ }^{5}$

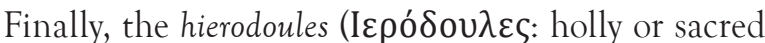
slave) were enslaved young women or female priests who served the sexual needs of visitors at various temples. ${ }^{6}$ All the above categories of prostitutes wrote a series of works on love and sexual intercourse to be read by men and at the same time they had composed various scientific treatises on hygiene and medicine. Their experience as prostitutes gave them empirical knowledge of human nature and required understanding of the various stages of a woman's menstrual cycle, fertility and anatomy.?

Some of these women wrote poems, prose, and philosophical treatises on love and intercourse that had a great impact on men. Hetaires especially were taught to recognize changes in body shape due to menstrual cycle, fertility and age, to understand personal hygiene and cosmetics, and to observe pathological changes. Many learned anatomy and sexual knowledge from exploring the limits of the human body's capabilities for various forms of sexual intercourse,

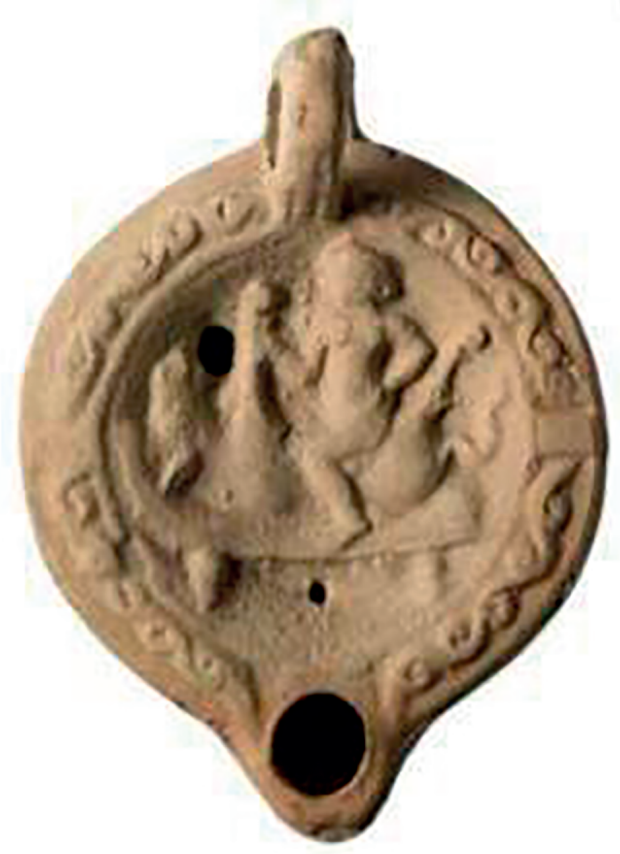

Figure 2. Terracotta oil lamp, Courtesan copulating with donkey, single-nozzle lamp (lychnos), ca. 150-250 AD, Nicosia, Cyprus Museum. including with animals and birds. This knowledge contributed to the medical revolution of that era.

It is possible that men wrote these texts using pseudonyms of prostitutes in the hope that their writing would be read by the general public.,7-8 Pliny testified about the existence of pornographic prose containing fragments of medicine, pharmacology, and philosophy, including themes of gynaecology, obstetrics, dermatology, sexually transmitted diseases, cosmetics, ethics, sexual behaviour, love, abortion, hydrotherapy, and anatomy. Some of these women authors were recognized as physicians, while others were simply experienced lovers, as shown in Figure 2.9

Public and private hygiene issues were among the primary concerns of prostitutes in ancient Greece. They specialized in abortive potions, erotic potions, as well as sedative, palliative, and narcotic medicines. They were familiar with the diagnosis and treatment of various venereal and dermatological diseases. They developed herbal cosmetics, mineral poultices, and aromatherapy treatments. They introduced and practiced massage therapy for erotic and analgesic purposes. Many also used balneotherapy (hierodoules), a popular method of bathing for personal hygiene, treating illness, and purification of the soul before

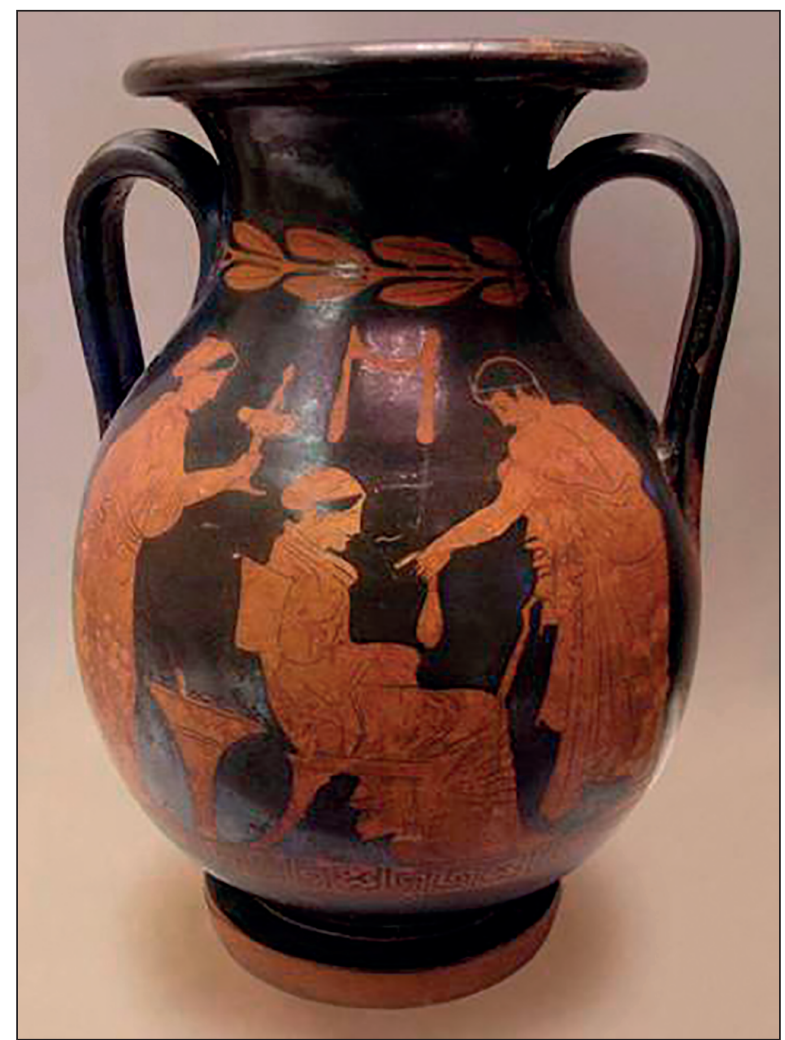

Figure 3. Youth giving a purse to a sitting hetaira. Behind her stands a young woman carrying a plemochoe. Attic red-figured pelike by Polygnotos, ca. 430 BC, Kameiros, Rhodes. 
sexual activities. They proposed nutritional habits and introduced holistic concepts, such as soul and body homeostasis, as parts of a healthy-living regime. These women contributed to the fields of midwifery and obstetrics by establishing medicinal practices and nomenclature. ${ }^{5,10-11}$ Moreover, the taxes paid by female prostitutes funded public hygiene efforts, such as sewers and public baths, as depicted in Figure 3. ${ }^{6}$

Philaenis ( $\Phi\left\llcorner\lambda \alpha \varepsilon v i\right.$ (s) of Samos (ca. $4^{\text {th }}$ century $\mathrm{BC})$ was the daughter of Okymenis and a prostitute. She wrote an erotic handbook, "About Pleasure

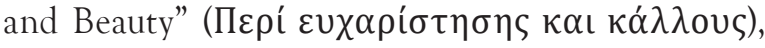
that was mentioned by the historiographer Timaeus Tauromenium (350-260 BC) and the stoic philosopher

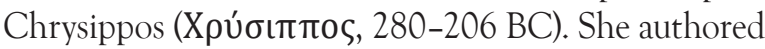
the guide in Samos, a place known for its lack of ethical, moral, and sexual taboos. Although today only fragments of this text remain, preserved in a papyrus, "About Pleasure and Beauty" is one of the first systematized forms of erotic art to discuss ways to improve sexual performance, such as the correct way of kissing. $5,12 \cdot 13$

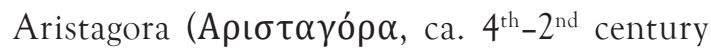
BC) was a hetaira from ancient Corinth. Plutarch and Athenaeus mention Aristagora as the hetaira of Hyperides. ${ }^{14-15}$ She was an expert in cosmetics, aphrodisiac potions, and ways to induce a man's erection. ${ }^{16-17}$ Elephantis or Elephantini (E $\lambda \varepsilon \varphi \alpha \nu \tau i$ s, or E $\lambda \varepsilon \varphi \alpha \nu \tau i ́ v \eta, 1^{\text {st }}$ century AD), an ancient Greek poet and physician and most probably a hetaira, also was renowned in the classical world as the author of a notorious sex manual titled, Sexual Intercourse Schemes (Пгрí

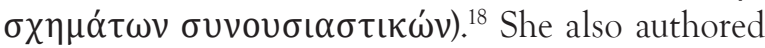
the handbooks On Cosmetics and On Abortion (Пع pí

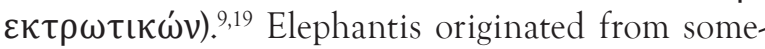
where near the Egyptian river Nile, where magic was strongly associated with healing arts. She wrote that menopausal fluids could cause infertility, abortion, and even prevent storms. She was among the first female figures to espouse the importance correct nutrition., ${ }^{9} 20$

Lais (Greek: $\Lambda \alpha^{\prime i} \zeta{ }^{\text {st }}$ and $2^{\text {nd }}$ centuries AD) was an ancient Greek slave from Sicily who became a famous prostitute in ancient Corinth. ${ }^{21}$ She went on to become a capable physician and midwife known for her disagreements with Elephantis. Fragments of her work, which were saved by Pliny, note her views that menopausal fluids could be used as an abortifacient, a fertility drug, as well as a cure for malaria $(\varepsilon \lambda \kappa \omega \dot{\delta} \delta \eta \varsigma$

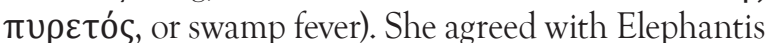
that these fluids also could drive away storms. ${ }^{9}$

Eventually, prostitution would be considered a threat to the general people and a scourge among the social classes. Regulations and inspections were re-introduced, and the public turned came to believe that the spread of venereal diseases was due to the prostitutes. Thus, the ancient Greek pornes used their knowledge to work with state inspections and registration and prevent disease so that prostitutes could gain a place in society, which is in stark contrast to the modern view of female prostitutes as women who have lost respectability due to their neglect of education and hygiene. Greek porneia were housed in synoiki-

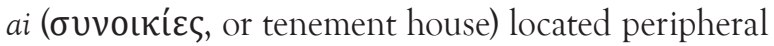
to the city. ${ }^{22}$ Archaeological remains of synoikiai are rare, suggesting a change in societal attitudes. Greeks may have anticipated this stigma, which might explain why they created a category of religious prostitute, the hieres, to avoid such desecration. ${ }^{23-24}$

From the early days of prostitution, pornes tried to enhance their natural looks in response to their customers' desires. For example, hair colouring was a common practice, as blonde hair was considered a symbol of innocence and beauty among people in Mediterranean area. Chewing mastic resin kept breath fresh for intimate kisses, and bathing with herbal oils helped maintain body hygiene. Cosmetics enhanced beauty and were considered a necessity among successful prostitutes. Even the non-educated pornes had a basic knowledge of beauty and aesthetic products. ${ }^{25}$

Prostitution in ancient Greece symbolized both lust and sexual freedom of women, while at the same time it could signal the relationship of female potency to control men. Prostitution thrived in Greek antiquity in places like Corinth, Samos, Lesbos, Athens,

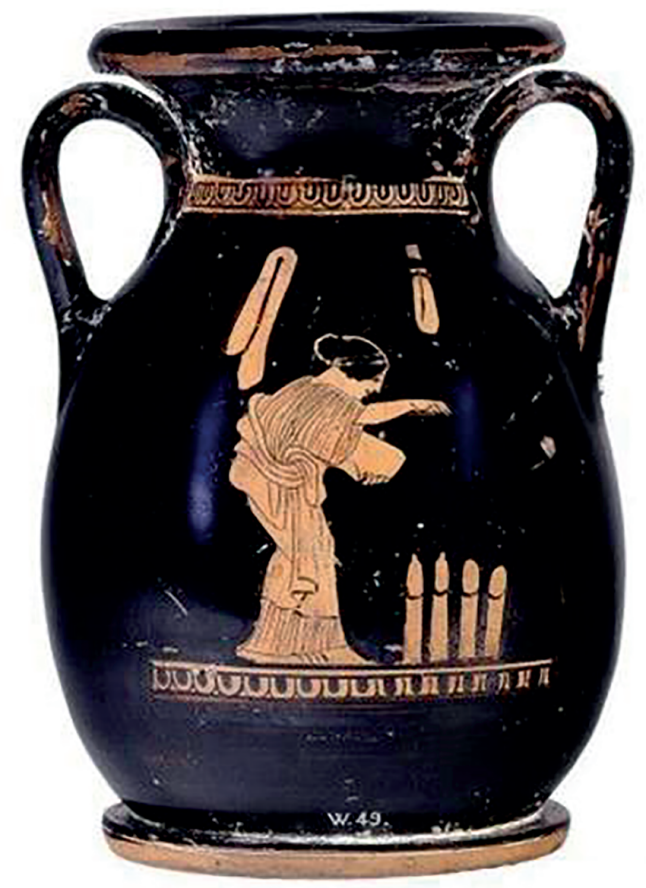

Figure 4. A hetaira tending phalloi, red-figured pelike, ca. $440 \mathrm{BC}$, British Museum. 
Delos, Ephesus, and Egypt. It occurred in brothels, in the streets, and in temples. Slaves and freed women, as well young women and sophisticated hetaires, served as prostitutes (Figure 4). These women also served as sources of medical literature. Most prostitutes served men in need of medical and psychological services. Thus, it was imperative that prostitutes knew how to provide such care. They also addressed issues like physical violence, sexually transmitted infections, post-traumatic stress, and unplanned pregnancies. ${ }^{26}$

\section{Conclusions}

Ancient Greece offers various works on eroticism and sexual health. The broad contribution of ancient Greek pornes, mainly from hetaires in ancient Greece, demonstrates the polysemous development of terms such as sexual pleasure, lust, and eroticism in the medico-philosophical texts of that era. The work and experience of prostitutes in ancient Greece has contributed to modern understanding of ethics, censorship, homosexuality, erotic education, personal hygiene, and cosmetics, as well as many medical topics, such as obstetrics, psychology, sexually transmitted diseases, epidemiology, pharmacology, and family planning. The peculiar relationship of prostitution, hygiene, and medicine may explain why prostitution in ancient Greek society enjoyed wide social acceptance. The modern world has benefited from the ancient Greek's acceptance of prostitution as an inevitable component of modern human sexuality.

\section{Author Contributions}

G.A., S.M., G.A., N.V., M.K. conceived the original draft preparation. G.A., S.M., G.A., N.V., M.K. were responsible for conception and design of the review. G.A., S.M., G.A., N.V., M.K. were responsible for the data acquisition. G.A., S.M., G.A., N.V., M.K. were responsible for the collection and assembly of the articles/published data, and their inclusion and interpretation in this review. G.A., S.M., G.A., N.V., M.K. contributed equally to the present work. All authors contributed to the critical revision of the manuscript for valuable intellectual content. All authors have read and agreed with the final version of the manuscript.

\section{Conflicts of interest}

The authors have no conflict of interests to disclose.

\section{Funding sources}

No funding sources need to be credited.

\section{Acknowledgements}

None

\section{References}

1. Epicurus. Morals. London, S. Briscoe, 1712.

2. Laios K, Tsoucalas G, Kontaxaki MI, et al. Mental health and sexual activity according to ancient Greek physicians. Psychiatriki 2015;26(3): 198-203.

3. Licht H. Sexual life in ancient Greece. London, Routledge, 1932.

4. Reisberg C. Marriage, hetaires and pederasty in ancient

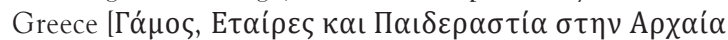
E $\lambda \lambda \alpha \dot{\alpha} \delta \alpha]$. Athens, Papademas, 1993.

5. Plan MI. Women writers of Ancient Greece and Rome. Chippenham, Antony Rowe, 2004.

6. Dillon M, Garland L (eds). Ancient Greece: Social and Historical Documents from Archaic Times to the Death of Alexander. New York, Routledge, 2010.

7. Bock G. Women in European History. Oxford, Blackwell, 2001.

8. Scott WJ. Gender: A Useful Category of Historical Analysis. The American Historical Review 1986;91(5):10534.

9. Plinius. The natural history. London, HG Bohn, 1857: 28.70, 28.77-86, 7.64.

10. Kampen BN. Sexuality in ancient art. Cambridge, Cambridge University Press, 1996.

11. Petropoulos H. Brothel [M 1980.

12. Timaeus. Timaeus von Tauromenium. Berlin, Wandsbeck, 1884: 12.13.1.

13. Athenaeus. The Deipnosophists [Banquet of the Learned of Athenaeus], vols 2. London, Henry G. Bohn, 1854: 5.220f.

14. Hubert C (ed). Plutarchus. Biographus et Philosophus.

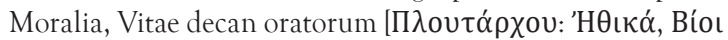

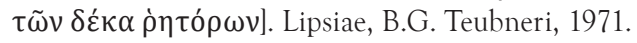

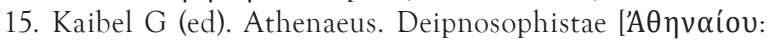

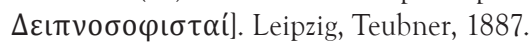

16. Chandler R. Travels in Greece: or an account of a tour made at the expense of the society of dilettanti. Oxford, Clarendon Press, 1776.

17. Kayser LC (ed). Flavius Philostratus. Epistulae et dialexis

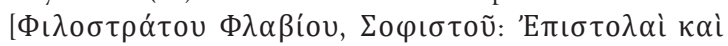
$\delta\left\llcorner\alpha \lambda \varepsilon^{\prime} \xi \varepsilon \iota \varsigma\right]$, in Flavii Philostrati opera, vol. 2. Leipzig, Teubner, 1871: section 1, epistle 22.

18. Publius ON. Opera Omnia. Philadelphia, Desilver, 1862: Ars III, 768.

19. Kayser LC (ed). Thais Med. Matrona, Nutrix, Obstetricia: Fragmentum, in Flavii Philostrati Opera, vol. 2. Leipzig, Teubner, 1871.

20. Galen. Claudii Galen opera omnia. Leipzig, Knoblogh, 1821: XII, 416

21. Bernadotte P (ed). Plutarch. Plutarch's Nicias and Alcibiades. New York, Charles Scribner's Sons, 1912: Nicias 15.4.

22. Glazebrook A, Henry MM. Greek prostitutes in the ancient Mediterranean, 800 BCE - 200 CE. Madison, University of Wisconsin Press, 2011.

23. Brockington CF. A short history of public health. London, J. \& A. Churchill, 1956.

24. Scott RG. A history of prostitution, from antiquity to the present day. New York, London, Rutledge, 2005.

25. Kapparis K. Prostitution in the Ancient Greek world. Berlin \& Boston, Walter de Gruyter, 2017.

26. De Chesnay M. Nursing research using phenomenology: qualitative designs and methods in nursing. New York, Springer Publishing Company, 2014. 